\title{
В.В. КОЛЕНОВА
}

\section{ТЕАТРАЛЬНАЯ КОНЦЕПЦИЯ АНАТОЛИЯ ВАСИЛЬЕВА: МЕТОДОЛОГИЯ И ЭСТЕТИКА}

\begin{abstract}
В контексте уникальной художественно-поэтической среды, главенствующую роль в которой играет концепция «школа лаборатория - театр», рассматривается творчество известного российского режиссера Анатолия Васильева, занятого поиском технологии этого баланса, а также его художественно-эстетическим наполнением.

Ключевые слова: Анатолий Васильев, традиция в искусстве, художественный метод, методология, игровая структура, творческая лаборатория, философия творчества.
\end{abstract}

\section{PAБOTW KABAHCKOTO XYАOXHAK TA. MEABEA EBA B ФOHAAX HALUOHAMEFOTO MV3E PMD MEHI T.EIBCEEBA}

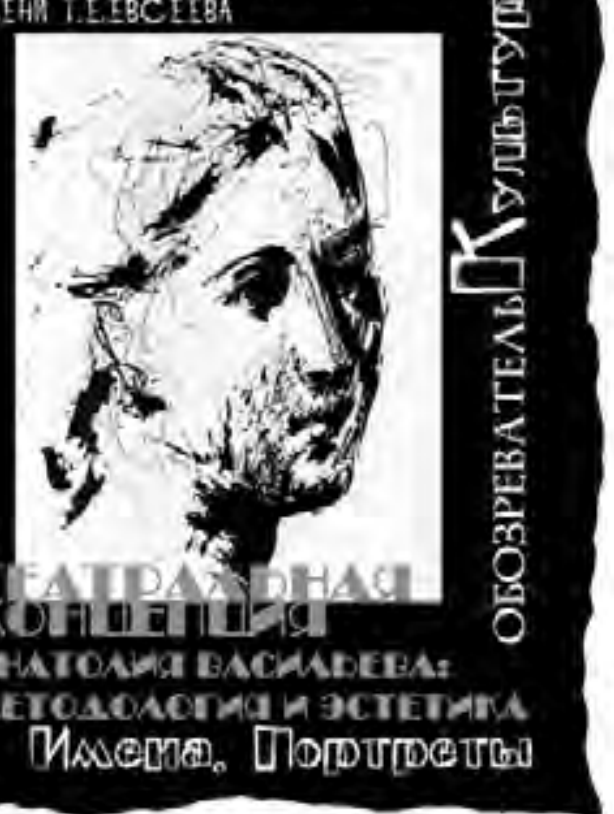

$\mathrm{H}$ астоятельная и наиболее актуальная задача для современного театра - опубликование и изучение тех теоретических и методологических идей, которые накоплены в области театрального искусства в последние десятилетия. Беседы с актерами театра «Школа драматического искусства» убедили автора данной статьи в том, что теоретические и практические знания, которыми они обладают, могли бы быть интересны и полезны актерам и режиссерам других театров, равно как и широкому кругу деятелей сценического искусства в России и за рубежом.

Методология, которую разрабатывал режиссер Анатолий Васильев на протяжении нескольких десятилетий, наследует основные положения системы К.С. Станиславского, сторонника театра как процесса воссоздания жизни человеческого духа. Именно эти аспекты системы Станиславского составляют сердцевину тех опытов, которые проводит Васильев в игровых структурах, будучи

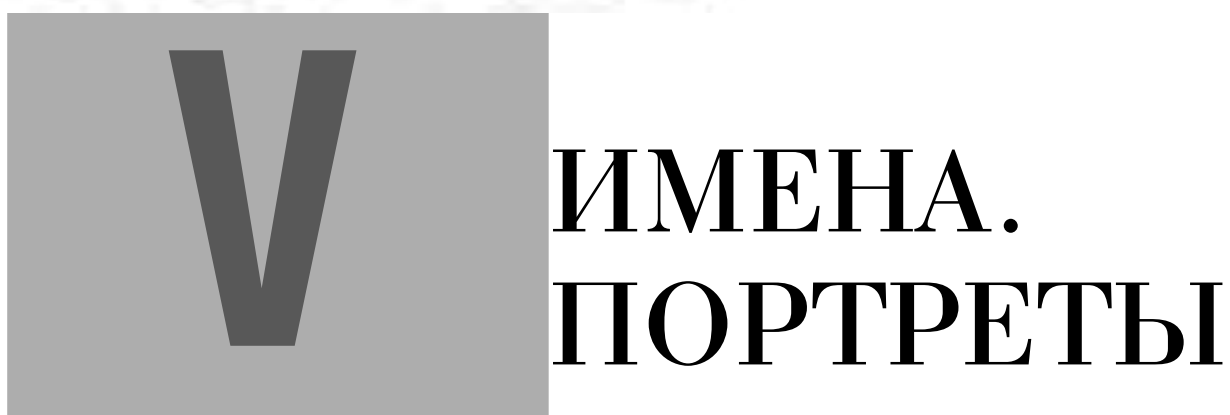


верным последователем русской актерской и режиссерской традиции.

Васильев интуитивно вскрыл проблему соотношения театра переживания и театра представления. Без особого философско-теоретического осмысления эти определения, родившиеся в суете репетиционного быта, легко запечатлелись в сознании театральных деятелей, запомнились своей простотой и ясностью и оказались чрезвычайно удобными для употребления. Их формулировок оказалось достаточно, чтобы, в конце концов, разложить всю картину мирового театра по двум «полочкам». Понимание театра как диалектического процесса было тем самым обеднено. Родившись вне всякой теории и философии, эта терминология вскоре стала основанием для всевозможных рассуждений и домыслов, результатами которых уже нельзя было не пользоваться в дальнейшей работе. Отсюда пошла путаница не только теоретическая, но и эмпирическая: если Станиславский, то непременно отец «театра переживания», если Мейерхольд - то основоположник «театра представления». Вахтангову всегда отводилось необоснованное и неотрефлектированное место между этими корифеями. Однако простого разделения оказалось недостаточно, и тогда речь пошла о том, что один вид театра находится в непримиримом идейно-художественном противоречии с другим. Художников самых разных эстетических концепций искусственно помещают в противоборствующие лагеря.

Сегодня, с высоты накопленного театрально-эстетического опыта, исследователь имеет возможность заново осознавать процессы как двигавшие и развивавшие театр, так и тормозившие его развитие, мешавшие ему. Как представляется, прежде всего необходимо освободиться от легковесной терминологии, раз и навсегда согласившись с тем, что условное противопоставление одной школы другой, их манер и форм, ведет театр к застою.

Творческая деятельность Анатолия Васильева показала динамику процесса движения разных театров навстречу друг другу. В своей статье «Новая реальность пространства» режиссер рассуждает об эмоциональных способностях художника, указывая на их природу, которая развивается эмоциональными, рациональными и духовными средствами, и сопоставляя их с «поиском эстетической новизны» [1, с. 272].

Для Васильева каждый автор - это новая театральная вселенная, каждый спектакль - проверка еще одной режиссерской догадки, еще один этап в творческой биографии. Режиссер все больше склоняется к выводу, что «синтез игровой, прагматической культуры Запада и спиритуальной, духовной психологической культуры Востока» [1, c. 274] необходим, поскольку возможно именно он станет единственным залогом выживания театра в XXI веке.

Вышесказанное в большей степени относится к технике и методологии театрального дела. Что же касается содержания, тут Васильев более традиционен. В нем говорит, скорее, практик, чем теоретик искусства, когда он замечает: «Русская культура всегда должна оставаться культурой реалистической, всегда должна повествовать о жизни человека и его таланте. И если она перестает повествовать о талантливом человеке, то она перестает находить спрос, публика перестает ею интересоваться» [1, с. 274].

Но как найти ту самую эстетическую новизну, если качественного слияния восточной и западной культуры не произошло?

Поиску разрешения этой «интриги» Васильев посвящает жизнь. И если с кем-то и сравнивать его путь, то, конечно, с Ежи Гротовским (1933-1999), польским режиссером, педагогом и теоретиком театра. Одни считают, что А. Васильев «заигрался в Гротовского», другие уверены, что он прямо наследует польскому реформатору. «Если изучаешь профессию и владеешь ею в совершенстве, то всегда находишься в пограничной ситуации. Одними и теми же средствами можно сделать два противоположных произведения - для Бога и для дьявола. Но тот, кто не владеет в совершенстве мастерством, тот просто что-то делает, часто без разбора, не способен свести концы с концами, определить себя в каком-то одном стиле, найти этот стиль» [2, с. 26]. В подобной пограничной ситуации всегда находился и Е. Гротовский. Режиссеры были знакомы, осуществляли совместные проекты. Оба они, несомненно, фигуры харизматические, и оба вызывают в окружающих одновременно и трепет, и пиетет, и страх, и любовь. Им верят, как не верят себе. «Оба самоуглубленны и страстно устремлены к недостижимому. Оба искали, хотя и по-разному, основ, корней, почвы под ногами. Такое впечатление, что на них давил, не давая им покоя, культурный груз тысячелетий. Возможно, оттого, что в таких людях сильна память истории - они помнят и знают всех, кто был до них, - они становятся отшельниками» [3, с. 14].

Гротовский в конце концов ушел в философию и, казалось, всю оставшуюся жизнь мечтал забыть о времени, когда был театральным режиссером. Васильев, прослыв в театральной среде философом, в душе все же остается режиссером. 0н так и не порвал окончательно с «мирской» режиссурой. В какой-то момент, подобно Гротовскому, Васильев пытался перечеркнуть спектакль как цель, но ему это не вполне удалось. Он до сих пор колеблется в окончательном выборе между педагогикой и театром, строительством спектакля и строительством себя. В этих колебаниях суть его мучений - и счастье публики: хоть иногда у нее появляется возможность увидеть его новый спектакль за рубежом (кстати, подтверждающий его теоретические выкладки), а не только изредка наблюдать учебный процесс. Гротовский использовал свой старый театральный опыт для духовного совершенствования, перетворения личности. Васильев, совершенствуя свой дух в собственных экспериментах, все-таки ищет и общую «перспективу художественного обновления». Представляется, что Васильева волнует прежде всего «поиск эстетической новизны», в то время как Гротовского больше занимали этические поиски. Для польского режиссера изучение мировых пратеатральных форм, которое на практике происходило в его Театре- 
Лаборатории, было расширением и углублением его знаний о мире.

Театр-Лаборатория (первоначально как «Театр 13 рядов») Ежи Гротовского начал свою деятельность в сентябре 1959 года в Ополе, городе на юго-западе Польши с населением в 60 тыс. человек. Вся судьба этого театра - судьба самого Ежи Гротовского, которого А. Васильев назвал «мистиком и мечтателем, гением и искателем» [3, с. 14].

Театр-Лаборатория - это необычный театр. В его спектаклях, действительно, всегда присутствовала особая эстетика, что свидетельствовало о глубоких исследованиях в области театрально-сценического искусства. И сам Ежи Гротовский, и его коллектив всегда находились в состоянии поиска. Однако в театре, даже постулируя принцип вечного движения, обновления и поиска, нельзя обойтись без метода и системы. Так, в первоначальный период своей деятельности режиссер писал: «Главные, узловые проблемы актерского искусства <..> должны исследоваться методично» [4, с. 126]. Но в 1968 году в Театре-Лаборатории начинается особый период. Гротовский, за которым уже закрепилась репутация создателя «тренинговой системы», становится ее ярым противником. Он делает признание актерам: «У меня нет никакой доктрины. Я просто говорю то, что думаю. Все время. К счастью, мысли все время изменяются. Ведь с нами случается же что-то в жизни - в том, что мы делаем, чем мы занимаемся. В нас постоянно что-то изменяется» [3, c. 14]. Чем же так привлекла режиссера работа с актерами без системы?

Театр-Лаборатория Ежи Гротовского, безусловно, был отделен от сферы массовой культуры, но всегда был рассчитан на «познавательный элитаризм». Гротовский считал, что «театр должен стать праздничной конфронтацией - искусством элитарным не в смысле принадлежности к какой-либо человеческой общности, но для каждого человека в момент, когда он ощущает эту потребность интимной конфронтации» [3, с. 13]. Так, этот театр был эстетически близок позиции, высказанной в европейской культуре Ницше и 0ртегой-и-Гассетом, Шпенглером и другими, видевшими в массовой культуре проявления «дегенерации» и «тривиализации». ТеатруЛаборатории не был чужд и определенный академизм. Парадоксально, но сам коллектив быстро стал популярен именно в среде массовой культуры. По воспоминаниям современников, он был «экзотичен», «непонятен», «оригинален» [3, с. 13], актеры вели аскетичный и замкнутый образ жизни, они откровенно чуждались артистической и богемной среды, что также вызывало немалое любопытство.

Очень скоро коллективу присвоили в прессе титул «первоклассной культуры» и высшую категорию. Гротовским были поставлены «Кордиан» Словацкого, «Акрополь» Выспянского, «Гамлет» Шекспира, «Трагическая история доктора Фауста» Марло, «Стойкий принц» Кальдерона, «Apocalypsis cum figuris» и многие другие. В чем же секрет столь невероятной популярности замкнутого и таинственного коллектива?
Для ответа на этот вопрос необходимо рассказать о специфической политике, которую вел театр в отношении зрителя. Далеко не все зрители допускались смотреть спектакли Ежи Гротовского. Анастасьев в своей статье «Лаборатория Ежи Гротовского» сообщает, что «на спектакле "Акрополь" зрителей, принимающих участие в действии, было 50 человек. На спектакле “Стойкий принц” - 35, на "Апокалипсисе" - 30. Репетиционный период работы над спектаклем все время увеличивался - “0рфей" репетировался три недели, а "Апокалипсис" - 3 года. Кроме того, спектакли шли 2-3 раза в неделю» [3, с. 13].

Гротовский и его театр при всем внешнем антирационализме все же обращены к миру, причем к тому, что всегда конкретен, осознаваем и имеет смысл. Они хотели бы примирить человека с миром и с самим собой. Жизнь в театре понимали сквозь призму философии. 0 Гротовском и его театре не раз говорили как об общине, имеющей определенную («свою») религию. Представляется, что это не совсем верно, так как театр был обращен не к вере, а к знанию и опыту. В 1967 году И. Шток называл Лабораторию Гротовского «психоаналитической “театрализованной лечебницей", где зрителей-пациентов подвергают встряске, возвращая театру первородную магию и античный катарсис» [3, с. 14]. Б. Ростоцкий, в свою очередь, называет «Театр 13 рядов» «психодраматической общественной системой, в которой была реализована попытка создания “терапевтически-творческого коллектива"» [4, с. 119].

Сама по себе Лаборатория была малой творческой группой. В 1959-1970 годы в ее состав входили восемь актеров, директор, художественный руководитель и режиссер в одном лице, руководитель литературной частью. Однако несколькими годами позже коллектив уже насчитывал несколько десятков человек. В этом театре воспринимали художественную задачу как свою собственную судьбу, как личный учебный процесс; искусство актеров выражало их истинные, а не ролевые переживания. Поэтому в конце 60-х годов Гротовский переименовал свой театр - он стал называться «Институтом».

Конечно, наукой в обычном смысле в «Институте» Гротовского не занимались, зато все время пребывали в эксперименте. Гротовский был сосредоточен на актере и его технике. Все корифеи актерского искусства (К.С. Станиславский, В.И. Немирович-Данченко, М. Чехов, В.Э. Мейерхольд, Б. Брехт и др.) писали о том, что актерское искусство имеет главную особенность, не знакомую другим видам творчества: актер должен творить собой, и тогда, когда это необходимо. Данный процесс Е. Гротовский стимулировал «самообнажением» актера, то есть полным раскрытием своей личной психики, вплоть до подсознания. Для этого, по его мнению, должны существовать не только внутренние стимулы, но и внешние - их актер должен «уметь брать» сам. Так Гротовский добивался совершенно невероятного. Он считал, что возможно элиминировать из творческого процесса психические и физические препятствия, вызванные собственным организмом. А потому Ежи Гротовский утверждает и неоднократно повторяет в своих работах, что индивидуальность 
актера, безусловно, нужно развивать, но развитие этой индивидуальности, прежде всего, связано с избавлением от старых привычек и штампов.

Таким образом, очевидно, что существование театралаборатории как института изначально требует аскетичного существования в актерском искусстве, задает полную отдачу профессии и служению искусству без остатка. Понятно, что подобная лабораторная работа также требует подчинения определенной системе и определенному специфическому тренингу. Более того, можно сделать вывод о том, что подобный экспериментальный театр несет в себе серьезную воспитательную функцию. Почему же театр, богатый столь уникальным багажом техники, идей и форм, Ежи Гротовский называл все-таки «бедным театром»?

В Театре-Лаборатории Гротовского действительно не было никаких театральных «украшений», как не было сцены и кулис, декораций и реквизита в привычном смысле слова. Даже количество предметов на сцене было ограничено. Каждый предмет сам по себе был некой ценностью, он тоже играл в пьесе, входил в ее динамику. Одна и та же вещь могла использоваться в спектаклях в многообразных качествах. Например, в спектакле «Акрополь» ванна употреблялась и по своему прямому назначению, но и вырастала до символа, ибо это была ванна, где человеческие тела перерабатывались на мыло и кожу. Если же ее перевертывали вверх дном, то она становилась «алтарем», перед которым заключенные читали молитву. Если ее ставили на возвышение, то она превращалась в ложе Иакова. Сам же мир предметов, их превращений, сопровождался и соответствующими звуками. Так, «музыкальным оформлением» служили скрежет по металлу, стук молотков, забивавших гвозди, которые кому-то напоминали отзвук колокольного звона. И только один действительно музыкальный инструмент часто использовался Гротовским это скрипка. Ее лейтмотив часто звучал и в лирические моменты, и как эхо свистков, и даже как сигнал охраны.

И все-таки главной ценностью для Гротовского был живой актер. В «бедном театре» он взял на себя бремя выражения страдания, отчаяния, горя, радости. Актер Лаборатории умел играть «частями тела»в том смысле, что, разные, они выражали различные же состояния, часто друг другу противоречащие. Артисты использовали жесты и позы в стиле пантомимы. Каждый имел свой собственный силуэт - и это тем более интересно и трудно, если само «задание спектакля» связано с повествованием о житейских невзгодах (именно эта тема являлась главной в творчестве Гротовского). Актеры мастерски владели голосом и речью: они умели говорить нечленораздельно, стонать, реветь как животные, исполнять нежные народные песни и литургические песнопения, использовали говор и поэтическую декламацию. Вся техника всегда применялась актерским ансамблем импровизационно. Думается, в этом и заключается главное открытие режиссера Гротовского, которое сделало каждый его спектакль явлением растущим и меняющимся, а потому и неким завершенным произведением искусства, но всегда живым и творимым только сейчас.
В 1970-е годы начинается новый этап в жизни Театра-Лаборатории, или Института мастерства актера. Критика назвала его этапом «активной культуры» ${ }^{1}$. В чем же его особенности?

Именно тогда Гротовский был занят такими проблемами творчества, которыми до него никто не занимался: он хотел сделать так, чтобы совершенно сторонние и никогда не видевшие друг друга люди могли, придя в театр, действовать и взаимодействовать. Гротовский назвал это Праздником. Значит, главным становился человек сам по себе. В театре происходила встреча с другим человеком. Такую непонятную на первый взгляд практику режиссер применял не только в помещении театра, но и в лесу, на природе. Эти действа должны были раскрыть в человеке его подлинное существо, которое не прячется от других. Он должен «действовать самим собой» [3, с. 13], а для этого Гротовский создавал так называемый действенный процесс. В его программе появляются такие определения, как «транскультурная деревня» или «монастырь культуры». Подобное естественным образом совершенно отпугивало одних и, наоборот, притягивало других. Для опытов Е. Гротовского город выделил под Вроцлавом шестнадцать квадратных километров незаселенной земли. Там он и продолжал свои эксперименты. По сути, это была деятельность, которая позже в искусствоведении стала называться паратеатральной, или послетеатральной. Высшей точкой этого периода стало создание Университета поисков. Сюда съезжались самые выдающиеся режиссеры мира - Барро и Брук, Ронкони и Чайкин, Грегори и Барба, и многие другие.

В чем же состояло значение таких встреч для развития мирового театрального искусства? Во-первых, здесь занимались изучением истоков театра (у Гротовского даже появился «Театр Истоков»), что означало стремление к сохранению человеком в себе зачатков древней культуры. Во-вторых, Гротовский продолжал двигаться в заданном в начале своего пути направлении - познать самого себя.

Исходные эстетические позиции Ежи Гротовского, которые впоследствии активно утверждал в своем творчестве Анатолий Васильев, состоят в следующем:

- театральное искусство автономно, живой театр лишь отталкивается от литературы, но ни в коем случае не иллюстрирует ее;

- театр вступает в контакт со зрителем не через литературную ткань, а путем конденсации чувств, спонтанности актерской игры. Поэтому сам Гротовский воспитывал нового артиста, который мог играть с полной физической отдачей, абсолютной психологической самоотдачей и вместе с тем был наделен чувством идеального самоконтроля и дисциплины;

- необходимо качественно исследовать законы зрительского восприятия;

- Театр-Лаборатория - это изучение технических и творческих проблем посредством постоянного прак-

\footnotetext{
${ }^{1}$ Для темы данной статьи этот период наиболее интересен, так как по своей сути он максимально схож с экспериментальным лабораторным творчеством Анатолия Васильева. - В.К.
} 
тического эксперимента при обращении особого внимания на искусство актерской игры;

- Театр-Лаборатория должен исследовать поставленные проблемы со строго научной точки зрения, с правом на эксперимент и ошибку, с проверкой своих открытий практикой. У него есть собственные проблемы: общественные и эстетические интересы именно данного театра, свой вкус, свой репертуар, своя эстетическая концепция;

- режиссер обязан опираться на опыт многих художников и философов;

- необходимо требовать от актера буквального ответа на вопрос, что он будет делать в реальной обстановке сегодняшнего спектакля? Это должно рождать виртуозную импровизацию в технике.

Однако главным эстетическим каноном Ежи Гротовского стало стремление к тому, чтобы зритель, воспринимающий его спектакли, чувствовал не только полную самоотдачу актеров, совершенное слияние их физического и психического начал, но и ощущал небывалую активность спектакля, словно артисты атаковали зрителя, наступали на его сознание, его природу, его эмоции. Именно этот накал, максимально содержащийся в опытах Гротовского, побудил задуматься художников новой эстетической веры, и Анатолия Васильева в том числе, о действенной, захватывающей силе искусства.

Кардинальной идеей всего творчества А.А. Васильева становится идея создания игрового театра. К нему он шел постепенно. Начало этого пути лежит в том периоде, когда он работал над спектаклем «Взрослая дочь молодого человека». Тогда и начались его поиски, которые не завершены еще и сегодня.

Идею игрового театра следует рассмотреть отдельно, чтобы понять ее конкретное театральное содержание. Для этого стоит вернуться к тезису о разнице между психологическим и игровым театрами, который был заявлен ранее. Коренное различие между ними общеизвестно. Психологический театр строится на самоотождествлении актера со своим персонажем, игровой - на дистанции актера и персонажа.

В психологическом театре актер глубоко погружается во внутренний мир персонажа: стремится усвоить мотивы действий и поступков, оправдать их, обрисовать характер и психологический склад героя, соотнести их с внешними чертами персонажа и т. д.

В игровом театре актер дистанцируется от персонажа, играет им, «показывает» его, выражает к нему то или иное отношение, стоит над ним, управляет им. В психологическом театре зритель отождествляет себя с персонажем, которого играет артист. В игровом театре зритель отождествляет себя с актером, который играет персонажа. В психологическом театре артист «не знает» финала роли, к которому придет персонаж в основном событии. Отождествляя себя с персонажем, актер шаг за шагом, этап за этапом изнутри проживает всю линию его жизни. В игровом театре артист знает этот финал, знает, к чему придет персонаж, поэтому, по выражению Васильева, он «играет от будущего».
Собственно игровым театром Васильев займется только после того, как будет создана «Школа драматического искусства», уже после «Шести персонажей в поисках автора», когда обратится к Достоевскому и Платону. Тогда и возникнет та эстетика и методология игры, которой режиссер пользуется вплоть до сегодняшнего дня.

Вот что говорил Васильев в своих публичных выступлениях в 1997 году: «Меня интересует актер, который не является персонажем. Мне более не интересно, чтобы актер представлял себя как какой-то персонаж. Я хочу его видеть как персону, как поэта, как личность. Его самого и больше никого. Я не хочу, чтобы он был исполнителем воли режиссера, я не хочу, чтобы актер был рабом персонажа, я даже не хочу, чтобы актер был рабом пьесы. Я хочу войти в зал и увидеть исключительную личность, я ожидаю от этой личности открытий, театр я перестал понимать как средство для того, чтобы воспитывать публику. Мне кажется, что театр - это опыт, который делают сами актеры» [4, с. 23].

Игровой театр был всегда и жив поныне. Жив в сохранившихся драматургических образцах и в тех школах актерской игры, о которых мы, к сожалению, знаем далеко не всё, потому что их методики никогда не записывались на бумаге, а передавались из поколения в поколение в живой актерской традиции. Игровой театр представлен уже в XX столетии великими режиссерами - В.Э. Мейерхольдом, Е.Б. Вахтанговым, А.Я. Таировым и гениальным актером М.А. Чеховым, П. Бруком, Дж. Стреллером, Ю.П. Любимовым. Игровой стиль в актерском исполнении встречается и на современной российской сцене. Но он развивается стихийно и неосознанно, а главное, не обладает необходимым художественным качеством и органикой, потому что артистам, воспитанным на системе Станиславского, трудно его «держать».

Обо всем этом, конечно, Анатолий Васильев знает. Именно это знание и толкнуло его на разработку особой игровой техники актера, в которой он соединил достижения предыдущих мастеров и свои собственные наблюдения. Васильев отнесся к этой проблеме как к проблеме фундаментальной, научной, которая должна быть всесторонне проработана практически и теоретически и оформлена в точных словах и понятиях. Все это было возможно только в условиях театра-лаборатории, концепцию которого разрабатывал Ежи Гротовский. Николай Чиндяйкин, а именно ему были поручены многие проекты в театре «Школа драматического искусства» совместно с Гротовским, вспоминал: «Васильев и Ежи Гротовский находятся в одном статусе. Статус для меня - это то, на каком уровне мятежности пребывает художник. На каком уровне мятежности он существует? А Гротовский и мятежность - это одно и то же. Гротовский говорил: я начал там, где закончил Станиславский. Он в отличие от всех нас обожал Станиславского. Поэтому для меня театр XX века - это Станиславский, потом Гротовский. Никаких промежутков. И в этом смысле статус Васильева как художника, как философа и человека, читающего мир и пытающегося с этим миром взаимодействовать, 
равен статусу Гротовского. Хотя это единственная фигура, перед которой Толя не стеснялся робеть. И единственная фигура, к которой Васильев мог отнестись с почитанием» [4, с. 245].

Создавая собственные игровые структуры, Анатолий Васильев, вне всяких сомнений, занял собственную философско-эстетическую нишу в театральном пространстве эпохи постмодернизма, которая сама подсказала художнику поиск в направлении лаборатории и театрального эксперимента.

Соблюдая точные количественные пропорции живого действия на сцене и заранее подготовленные и срепетированные структурно-игровые сцены в сочетании с условностью театрально-сценического действа, иногда с некими нарочито жесткими моментами, режиссер точно выполняет собственные философско-эстетические установки, рождая неповторимое эмоционально-поэтическое действо.

Материалистическое обоснование системы Станиславского, предпринятое в советское время, когда она стала основной методикой работы всех театров, не является абсолютно адекватным самому Станиславскому. Его метод сложнее, разнообразнее и глубже. И об этом как никто другой знает Анатолий Васильев, который продолжает быть пропагандистом системы. Он выпустил в Европе книгу своего педагога Марии Кнебель - книгу, отредактированную им самим, очищенную от материалистических акцентов и неких театральных предрассудков, которыми она была насыщена за долгое время существования чистого психологического театра; ведь без этого в СССР путь к публикациям был закрыт.

Но, очевидно, пришло время, когда психологическую школу Станиславского нужно было «реконструировать», как выражается Васильев, обогатить методикой подхода к драматургии не психологической и при этом сохранить в неприкосновенности сам метод действенного анализа, репетиционную методику этюда. На все это Васильев и опирается в своей режиссерской и педагогической деятельности.

Эти слова художника имеют фундаментальное значение для понимания его творчества, его метода, где вся театральная концепция строится на философии искусства в рамках театрально-эстетического эксперимента. Очевидно, как уже говорилось, что существование подобного театра возможно только в рамках лаборатории. С этим понятием неизбежно соединены две важные черты: вопервых, это систематические исследования, проводимые в данной области, а во-вторых - комплекс условий, которые делают проведение экспериментов возможным. Совершенно ясно, что идея театральной лаборатории в системе зрелищных искусств располагается где-то на одном полюсе с театром переживания, где сосредоточены поиски психологической правды, глубоко и полно проникающие в актерскую природу, ее феномен, значение и логику духовно-физических и эмоциональных процессов. В театре Васильева, как в каждой настоящей лаборатории, эксперименты действительно имеют научную ценность, потому что исследуется сама суть человеческого бытия.
Так театры-лаборатории становятся настоящими центрами исследований духовных процессов (МХТ под управлением К.С. Станиславского и В.И. Немировича-Данченко, «бедный театр» Е. Гротовского, «Мастерская Петра Фоменко», «Школа драматического искусства» Анатолия Васильева и многие другие).

Сегодня Эудженио Барба, Питер Брук и Анатолий Васильев, каждый по-своему, возвращаются к опытам, мифу и традициям лабораторного театра. Однако для последнего «лаборатория» - без сомнения, центральное понятие во всем его творчестве. Стоит вспомнить интервью Станевского, объясняющего его отношение к ТеатруЛаборатории Гротовского и «лабораторности» вообще: «Эксперименты, действительно, имели лабораторный характер. 0ни были закрыты, не связаны с общественным контекстом, касались, прежде всего, психологии, интимных переживаний, эксплуатации внутреннего мира личности <...> От ошибочного применения психологии или психоанализа предостерегал Клод Леви-Стросс, говоря, что это есть злоупотребление объяснениями-отмычками. А это может привести к ужасным поступкам, духовным мучениям <...>» [3, с. 13]. Однако в опытах Васильева личные переживания уникальным образом синтезируются с философско-эстетической формой всего спектакля, с художественно-эстетической подоплекой образа, с философскими ресурсами автора и эпохи.

Когда Станиславский начал создавать свою систему, вокруг него и его театра стала образовываться сеть студий; ученики Мастера развивали его идеи. Некоторые из них, например Евгений Вахтангов, Михаил Чехов, предложили свою интерпретацию психологической школы, обогатили ее новыми положениями и методологическими идеями.

Ученики есть и у Анатолия Васильева. Теперь уже от них театр вправе ожидать продолжения опытов, внедрения их в педагогическую практику. Правда, сегодня не такое время, когда можно надеяться на всеобъемлющее, тотальное распространение каких-либо методик. Это, однако, не означает, что у Васильева не могут появиться последователи.

Теория игровых структур совсем не обязательно должна иметь применение только в высоких мистериальных жанрах. Это может быть прерогативой самого Васильева, выражающей его эстетические и художественные поиски. Игровая теория, которую Васильев всесторонне разрабатывал в своей лаборатории и продолжает разрабатывать сегодня, - огромное невспаханное поле. В ней заложен большой потенциал для театра будущего.

Нельзя говорить, что Анатолия Васильева не интересует человек как таковой, что в его спектаклях нет живых людей. Такую точку зрения можно услышать даже от его учеников. Васильева человек интересует, но в очень определенном смысле: не как производное социальнобытовой среды со всеми вытекающими отсюда особенностями, начиная от манеры одеваться, разговаривать и заканчивая манерой размышлять. Васильева интересует человек в онтологическом смысле, в его взаимоотношениях с бытием. Что мы можем сказать о персонаже пьесы 
Беккета «В ожидании Годо»? 0 том, как он одевается, каковы его житейские привычки, на каком он ездит автомобиле? Ничего. Но мы можем многое сказать о его трагическом положении в мире, о его космическом одиночестве или о его взаимоотношениях с Богом [1, с. 190].

Новейшая европейская литература XX века (Ж.П. Сартр, Г. Гессе, Т. Манн, С. Беккет, М. Пруст, Х.Л. Борхес и др.) не занимается человеком как производным социально-бытовой среды. Она занимается именно онтологическим человеком, поставленным в сложный интеллектуальный, часто метафорический контекст культуры и цивилизации. Поэтому поиски Анатолия Васильева — это поиски художника, желающего соответствовать ведущим тенденциям литературы, драматургии, искусства XX и теперь уже XXI столетия в целом.

Известный испанский философ Х. Ортега-и-Гассет, обратив внимание на те изменения, которые произошли в искусстве XX века по сравнению с XIX, веком реализма, писал: «На протяжении XIX века художники работали слишком нечисто. Они сводили к минимуму чисто эстетические элементы и стремились почти целиком основывать свои произведения на изображении человеческого бытия <...> Творения подобного рода лишь отчасти являются произведениями искусства, художественными предметами. Чтобы наслаждаться ими, вовсе не обязательно быть чувствительным к неочевидному и прозрачному, что подразумевает художественная восприимчивость. Достаточно обладать обычной человеческой восприимчивостью и позволить тревогам и радостям ближнего найти отклик в твоей душе. Отсюда понятно, почему искусство XIX века было столь популярным: его подавали массе разбавленным в той пропорции, в какой оно становилось уже не искусством, а частью жизни» [5, с. 231].

Размышления испанского философа, выступающего ярым противником реалистического, житейски понятного искусства и массовой культуры, закономерно приводят его к следующему утверждению: «Новое искусство разделяет публику на два класса - тех, кто понимает, и тех, кто не понимает его, то есть на художников и тех, которые художниками не являются. Новое искусство - это чисто художественное искусство» [5, c. 103]. Театр Анатолия Васильева сегодня - красноречивый пример такого элитарного искусства, непонятного обычной публике, заполняющей сегодня другие зрительные залы.

Первым, что было написано в конспекте занятий в васильевской лаборатории у одного из лучших учеников Васильева (лауреата национальной премии «Золотая маска» в номинации «Эксперимент») Александра Огарёва, было следующее: «Преодолевая психологический театр, Васильев стремится преодолеть и тот стиль игры современного актера, к которому мы привыкли. Так называемый личностный стиль игры, когда актер черпает содержание роли не только изнутри своего персонажа, но и изнутри самого себя. Не только окрашивая, но во многом и формируя характер изображаемого лица собственной индивидуальностью» [6, с. 10].
Это и соответствует знаменитой формуле Станиславского «я в предлагаемых обстоятельствах». Но и современная актерская практика строится на предельном сближении персонажа и актера. Именно поэтому какие-то характеры, которые сыграл актер, навсегда срослись с его человеческой индивидуальностью. В своей теории игрового театра Васильев обнаруживает точки соприкосновения со многими режиссерами XX века. Может показаться, что его разделение на персону и персонажа чем-то напоминает эстетику игры в театре Бертольта Брехта, у которого актер отчуждается от изображаемого героя. Васильеву задавали этот вопрос. Он ответил: да, но различие в том, что у Брехта актер создает определенную социальную, политическую среду, а у меня актер погружается в художественно-философскую среду.

Итак, Анатолий Васильев существует на своей, особой территории. Он и сам любит повторять это слово «территория» и вкладывает в него серьезный смысл. Так на какой территории он находится сегодня? Совсем не на той, где озабочены скороспелым успехом и карьерой, где воюют и самоутверждаются, создают быстро проходящую моду, блефуют, гонятся за мнимыми и ускользающими победами, врут себе и другим, входят в раж, словно принимают допинги, чтобы обрушить шквал энергии и трюков на публику и повергнуть ее в шок.

Васильев находится на той территории, где отказываются от публичности и от всех связанных с ней обретений и потерь. Здесь существуют уединенно, как в монастыре в окружении только ближайших учеников и сподвижников-актеров (последние, правда, нередко возвращаются в жизнь, таящую так много соблазнов), где подчиняются тем внутренним законам и логике, которые почти не уловимы для непосвященных.

Анатолий Васильев по-прежнему существует на территории исследования, опытов, не приносящих быстрых результатов. При этом он уже многого добился. Создал особую методику работы с актерами. Распахнул двери в широкое пространство игровых или, как он их называет, универсальных структур. Поднялся до таких жанров, как мистерия и притча. Проник туда, где обитают идеи и высокие смыслы, в разреженное пространство метафизики, где не ощущаешь вздохов и лепета обыденных человеческих стремлений и страстей.

Режиссер Васильев преодолел психологический барьер. Ему претят обыденные переживания и драмы, расхожие чувства. Он вообще отрицает театр, как он говорит, светский, то есть, по существу, весь современный театр, плохой и хороший, отсталый и передовой. Он видит относительность всех предпринимаемых усилий и смотрит далеко вперед, туда, где произойдет эпохальная смена в культуре и родится что-то принципиально и неожиданно новое.

Понятно, что подобная система просто взрывает сознание артиста, долгие годы проповедовавшего театр психологический, самый экстремальный тренинг в котором - только в глубоко драматичных и трагичных этюдах.

В одном из интервью Александр Огарёв сказал: «Понятие "васильевские ученики" стало нарицатель- 
ным - его уже и сам Васильев не любит. Мудрый взгляд, значительное выражение лица, сразу видно, что человек владеет ключами от многих тайн <...> Такой образ мне не нравится. Школа Васильева состоит из двух частей: это изучение философии искусства, а затем - его технологии. И вот технологию многие упускают. Схватившись за философию прекрасного, которую преподает Васильев, они забывают о том, как это делается...» [6, с. 12]. Этот же момент Александр Анатольевич непрерывно фиксирует в своих конспектах: «философия искусства - технология <...> технология потом - сначала философия» [6, с.12].

В этом заключается главное доказательство того, что эстетические позиции Анатолия Васильева не интуитивные рассуждения о красоте и прекрасном, не надуманное пристрастие к замысловатой форме спектакля. Напротив, это абсолютное знание философии творчества, идущей от метафизического театра, переходящей к структурным игровым формам, к особой вербальной технике, к уникальному философскому мышлению, и завершающейся чистой и цельной эстетической концепцией всего спектакля.

«Здесь мы занимаемся тем, что ценилось еще со Средних веков, - изучаем мастерство», - считает Огарёв [6, с.11]. И это - правда, поскольку только так возникает та особая область театрального пространства, образуемая благодаря концентрации вокруг актерско-режиссерской деятельности и связанных с нею технологий, где каждый спектакль становится настоящим произведением искусства, являясь удивительным феноменом в культурно-эстетическом поле театральной действительности.

Специфическая чувственно-конкретная информация, созданная по законам художественной формы, способна оказывать глубокое художественно-творческое воздей- ствие на людей. Однако вступление в художественный диалог предполагает развитие таких элементов художественной культуры личности, как художественное образование, обучение, воспитание, практическая художественная деятельность. Анатолий Васильев не упускает и это, стремясь воспитать в артисте личность, у которой есть крепкая нравственно-эстетическая опора, позволяющая приблизиться к осознанию ее роли и места в театральном пространстве, в философии творчества в целом. Если мир есть совокупная реальность, вся действительность (природная, социальная, индивидуальная) как целое и целостность в ее прошедшем, настоящем, будущем, то бытие отдельного человека и человечества в мире специфично и уникально. И с эстетической точки зрения «также важно ответить не столько на вопрос о бытии человека, сколько на вопрос о том, как именно человек существует» [4, с. 309].

\section{Список литературы}

1. Васильев А., Богданова П. Новая реальность пространства // Советские художники театра и кино. Вып. 5. - М., 1983.

2. Васильев А. Театр - это душа, летающая в дождливом Батуми (беседа с Г. Кожуховой) // Советский театр. - 1983. № 3.

3. Станевский В. Гости старого театра. Встреча одиннадцатая (беседа с Малгожатой Дзевульска) // Старый театр. - Краков, 1994. - № 12.

4. Богданова П.Б. Логика перемен. Анатолий Васильев: между прошлым и будущим. - М.: НЛ0, 2007.

5. Ортега-и-Гассет X. Восстание масс. Дегуманизация искусства. Бесхребетная Испания. - М.: АСТ; АСТ Москва, 2008.

6. Игнатова С. Владимирский театральный фестиваль / сб. материалов. - Владимир, 2011.

\section{Э.М. КОЛЧЕВА, С.К. СВЕЧНИКОВ}

\section{РАБОТЫ КАЗАНСКОГО ХУДОЖНИКА Г.А. МЕДВЕДЕВА В ФОНДАХ НАЦИОНАЛЬНОГО МУЗЕЯ РМЭ ИМЕНИ Т.Е. ЕВСЕЕВА}

Изложены результаты изучения вклада казанского художника Г.А. Медведева в становление живописи в Марийском крае в первой трети XX века, в создании Казанской художественной школы. Особое внимание уделено двум картинам художника — «Сплав леса по реке Кокшаге» и «Степан Разин на Волге», представляющим интерес с точки зрения истории развития российского изобразительного искусства в целом. Статья подготовлена по результатам проекта РГНФ «Этнокультурное пространство в художественноэтнографических работах 20-30-х годов XX века из фондов Национального музея РМЭ им. Т.Е. Евсеева», № 09-01-24101 а/В. Ключевые слова: Г.А. Медведев, Казанская художественная школа, живопись 1920-1930-х годов, Национальный музей РМэ им. Т. Евсеева, марийская культура, Степан Разин. 